\title{
Identifying environmental constraints at the edge of a species' range: scallop Psychrochlamys patagonica in the SW Atlantic Ocean
}

\author{
Nicolás L. Gutiérrez ${ }^{1, *}$, Ana Martínez ${ }^{2}$, Omar Defeo ${ }^{3}$ \\ ${ }^{1}$ School of Aquatic and Fishery Sciences, University of Washington, Box 355020, Seattle, Washington 98195, USA \\ ${ }^{2}$ Sección Oceanografía, Departamento de Biología Pesquera, Dirección Nacional de Recursos Acuáticos, Constituyente 1497, \\ Montevideo 11200, Uruguay \\ ${ }^{3}$ UNDECIMAR, Facultad de Ciencias, Igua 4225, PO Box 10773, Montevideo 11400, Uruguay
}

\begin{abstract}
Recognizing the relationships between oceanographic variables and population descriptors has been a major step in understanding geographical range limits. In the present study, we investigate which oceanographic features are responsible for the decrease in fitness and consequent northern limit of the scallop Psychrochlamys patagonica distribution in Uruguayan waters of the SW Atlantic Ocean (SAO), based on information compiled from fishing and oceanographic surveys. $P$. patagonica showed clear population responses to physical variables, including a marked decrease in abundance, individual size and muscle weight towards the northern edge of the range. A generalized additive model (GAM) significantly explained $78.7 \%$ of the deviance in scallop abundance and retained all 4 descriptors in the model as significant, showing a decrease in abundance at lower latitudes with higher temperature and at lower values of chl $a$ and water depth. The performance of GAMs was compared with that of the equivalent generalized linear models (GLMs) and it was concluded that the extended flexibility offered by GAMs resulted in better overall fits. Spatial variations in scallop abundance were accurately predicted by the GAM, including the 2 peaks at latitudes $36^{\circ} 20^{\prime} \mathrm{S}$ and $36^{\circ} 50^{\prime} \mathrm{S}$. These spatial variations were closely related to the shelf break front around the $100 \mathrm{~m}$ isobath, where abundance was higher. The northern range limit of the species in the SAO may be caused by a sharp decrease in habitat quality, indicated by temperatures higher than $9^{\circ} \mathrm{C}$ (above species tolerance limit) associated with the influence of the Subtropical Water. Whereas physiological tolerance to temperature appears to be an important mechanism driving the range boundary of $P$. patagonica, food availability (reflected by the highest concentrations in chl a) is a key explanatory factor of the spatial variations in scallop abundance.
\end{abstract}

KEY WORDS: Psychrochlamys patagonica - Species borders · Environmental constraints . Generalized additive model · GAM · Southwestern Atlantic · Uruguay

Resale or republication not permitted without written consent of the publisher

\section{INTRODUCTION}

The distribution range of sedentary invertebrates is strongly influenced by their oceanic and benthic environment. Although such relationships are inherently dynamic, distributions have been related to a range of environmental features, including sea surface and bottom temperature (Jensen et al. 2005), salinity (Christophersen \& Strand 2003), water depth (Katsanevakis 2005), and food availability (Cusson \& Bourget 2005).
However, the importance of these factors appears to differ among regions and species, highlighting the importance of studying the role of oceanographic features in the distribution of benthic invertebrates on a regional basis (Portner 2002, Jensen et al. 2005, Kater et al. 2006).

Discontinuities in population density often correlate to abiotic boundaries; range limits may be hard (e.g. coastline) or soft (e.g. hydrographic gradient), and may be caused by single or multiple factors, both at single 
points and along the entire range margin (Sagarin et al. 2006). Given that environmental factors potentially involved in range limitation are frequently interrelated (Freeman \& Rogers 2003) and generally show complex patterns of variation across the environment, their analysis is sometimes not straightforward (Sagarin et al. 2006).

Scallops commonly have recurrent spatial distribution patterns that have been attributed mainly to dispersal and larval retention mechanisms associated with hydrographic features (Caddy 1989, Arnold et al. 1998). Therefore, many scallop fishing grounds are recurrent in location (Sinclair et al. 1985) and have been harvested for several decades (Stokesbury 2002). Those aggregations are spatially discontinuous (i.e. several $\mathrm{km}$ apart) and tend to be spatially coincidental with oceanographic (e.g. frontal systems) and habitat (e.g. substrate type) features that facilitate larval retention, food supply and maximize species fitness (Bogazzi et al. 2005). Oceanographic characteristics are also responsible for abrupt changes in scallop abundance, particularly close to geographical range limits (Heilmayer 2003).

The scallop Psychrochlamys ${ }^{1}$ patagonica is distributed along the SW Atlantic Ocean (SAO), between $35^{\circ} 50^{\prime} \mathrm{S}$ and $48^{\circ} 00^{\prime} \mathrm{S}$. Large associations or beds have been related to frontal zones (Bogazzi et al. 2005). In Uruguayan waters, P. patagonica occurs between $35^{\circ} 50^{\prime} \mathrm{S}$ and $37^{\circ} 00^{\prime} \mathrm{S}$ and between 70 and $120 \mathrm{~m}$ depth (Defeo \& Brazeiro 1994, Gutiérrez $\&$ Defeo 2003). This area is strongly affected by the confluence of the Brazil (warm and salty) and Malvinas/Falkland (cold) currents. The convergence between the northward Subantarctic Water (SAW) (Sverdrup et al. 1942, Thomsen 1962) and the southward Subtropical Water (STW) (Emilsson 1961, Thomsen 1962) defines a frontal zone with a prominent variation in temperature (Ortega \& Martínez 2007). This front, also known as the shelf break front (Acha et al. 2004), is characterized by high productivity (Carreto et al. 1995) and phytoplankton abundance (Brandini et al. 2000).

Previous studies in Uruguayan waters, which constitute the northern limit of Psychrochlamys patagonica distribution, showed marked spatial patterns in life

${ }^{1}$ We follow the recent generic re-allocation of Zygochlamys by Jonkers (2003) history traits (Defeo \& Gutiérrez 2003, Gutiérrez \& Defeo 2003) and population dynamics (Gutiérrez \& Defeo 2005), notably a decrease in abundance, growth and survival towards its northern limit (i.e. $35^{\circ} 50^{\prime} \mathrm{S}$ ). These patterns have been attributed to less favorable environmental conditions, but hypotheses about which oceanographic features are actually responsible for the decrease in fitness and consequent northern limit of the species distribution have never been tested. The present study investigates spatial patterns in abundance, individual size and muscle yield of the scallop $P$. patagonica in relation to oceanographic characteristics. To this end, a model-building technique was applied to determine and predict the potential sensitivity of scallop abundance to spatial variations in environmental change, particularly in the northern limit of its distribution range.

\section{MATERIALS AND METHODS}

Study area. The study focuses on the SAO between latitudes $35^{\circ} 50^{\prime}$ and $37^{\circ} 00^{\prime} \mathrm{S}$ and the 75 and $135 \mathrm{~m}$ isobaths. The total study area encompasses approximately $5100 \mathrm{~km}^{2}$ over the Uruguayan shelf (Fig. 1) and is characterized by an even bottom topography and water

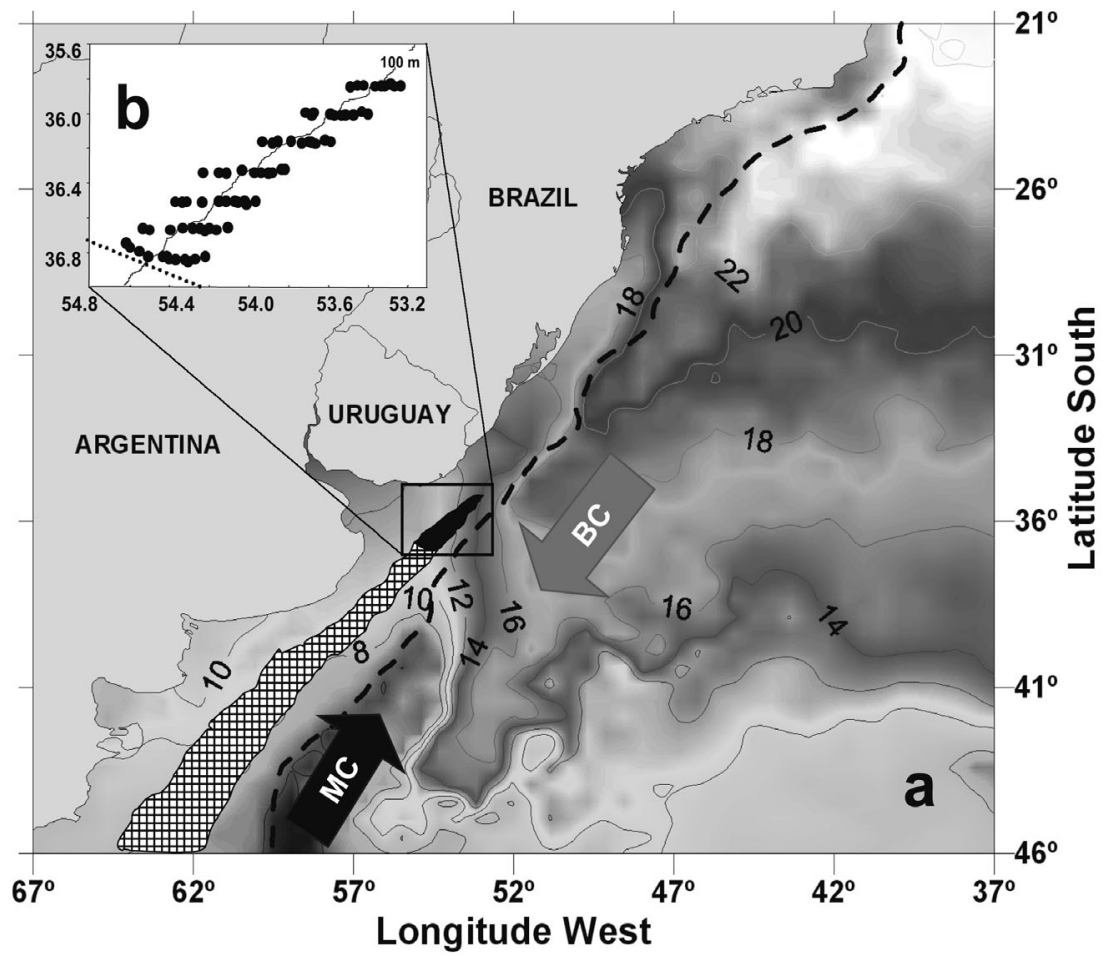

Fig. 1. Psychrochlamys patagonica. Study area in Uruguayan waters of the SW Atlantic Ocean: (a) cross-hatched area: species distribution in Argentinean waters; dashed line: $200 \mathrm{~m}$ isobath; sea surface temperature (SST) isotherms are also shown, highlighting confluence between Malvinas/ Falkland (MC) and Brazil (BC) currents; (b) sampling stations 
masses with contrasting thermohaline properties. The Tropical Water (TW) carried by the Brazil Current (Sverdrup et al. 1942) is restricted to the northern shelf and mixes with the STW in the water column during their southward flow. The water of the southern shelf, cold and relatively fresh, corresponds to the SAW which, during its northward flow, is mixed with the STW between the 100 and $200 \mathrm{~m}$ isobaths at latitudes lower than $36^{\circ} 30^{\prime} \mathrm{S}$ and $35^{\circ} 40^{\prime} \mathrm{S}$ during autumn and spring, respectively (Ortega \& Martínez 2007). Therefore, the Uruguayan shelf has a high degree of horizontal and vertical heterogeneity, with oceanographic processes affecting water column stability (i.e. shelf convergences) and providing favorable environmental conditions for spawning, nursery and breeding of fish and invertebrate populations (Bakun \& Parrish 1991).

Biological and oceanographic data. Data used to assess the stock of the scallop Psychrochlamys patagonica were collected during July 2001. Survey operations were conducted from the Uruguayan RV 'Aldebarán' in a strip of the continental slope $139 \mathrm{~km}$ long and $37 \mathrm{~km}$ wide (total area surveyed: $5100 \mathrm{~km}^{2}$ ). A total of 67 sampling stations were located systematically (by GPS) on parallel transects along the latitudinal gradient at 10 nautical miles $(18 \mathrm{~km})$ intervals between $35^{\circ} 50^{\prime} \mathrm{S}$ and $36^{\circ} 50^{\prime} \mathrm{S}$ and at $5 \mathrm{~m}$ intervals within the depth range 75 to $135 \mathrm{~m}$, until at least 1 sampling station without organisms was recorded. Thus, the survey covered the entire species distribution in Uruguayan waters. Each tow was carried out with an otter trawl directly attached to the doors (otter boards), a net opening of $9.5 \mathrm{~m}$ and a mesh size of $5 \mathrm{~cm}$, with a mean trawling speed of 3.2 knots over a 15 min towing time (Gutiérrez \& Defeo 2003). Some 11080 scallops were measured on board with callipers (1 $\mathrm{mm}$ accuracy) from the umbo to the ventral border of the shell (valve height $H$ ), representing the entire range of sizes typical for this scallop found throughout the study area. Laboratory measurements of total weight without epibionts and adductor muscle weight were made on an electronic balance with $0.01 \mathrm{~g}$ accuracy. Latitudinal variations in muscle weight of $60 \mathrm{~mm}$ scallops $\left(W_{60}\right)$ were estimated (except for $35^{\circ} 50^{\prime} \mathrm{S}$, where individuals were $<60 \mathrm{~mm}$ ).

Long-term oceanographic data were obtained from 10 annual surveys conducted from 1991 to 2001 with the RV 'Aldebarán,' where selected stations exactly matched all those of the scallop survey. Long-term information was averaged for each of the 7 latitudes and 12 depths $(5 \mathrm{~m}$ intervals between 75 and $135 \mathrm{~m}$ depth) in order to model the relationship between oceanographic and biological data. During these surveys, CTD (SBE-19, Sea-Bird Electronics) casts profiled the water column from the surface to about $5 \mathrm{~m}$ above the bottom. Water samples for biological analy- ses were taken with Niskin bottles. Immediately after collection, $1000 \mathrm{ml}$ samples were filtered through $47 \mathrm{~mm}$ diameter glass fiber filters (Whatman GF/C) for assessment of total chlorophyll. Filters were stored dried and frozen for subsequent analysis in the laboratory. Chlorophyll was extracted with $90 \%$ acetone and analyzed with a Shimadzu UV-2101 PC, UV-VIS Scanning spectrophotometer (Parsons et al. 1984). Total chl a was calculated according to Jeffrey \& Humphrey (1975). The mean $\mathrm{chl} \mathrm{a}\left(\mathrm{mg} \mathrm{m}^{-3}\right)$ at each station was estimated by graphical integration of the discrete values and then divided by the integration depth.

Data analyses. Information on biomass $\left(B: \mathrm{kg} \mathrm{m}^{-2}\right)$ at each station was calculated by the swept area method (Caddy 1979) as $B=C /(a e)$, where $C$ is the total catch in each haul, $a$ is the area swept by the gear (mean \pm SD: $5141 \pm 344 \mathrm{~m}^{2}$ ) and $e$ is gear efficiency, defined as the fraction of scallops in the path of the gear that are actually caught. This parameter was set at 0.35 , according to precautionary estimates provided by Lasta \& Iribarne (1997).

Single relationships between population and oceanographic variables (mean estimates for each latitude and depth) were modeled by linear or nonlinear fitting, and the model that best explained the relationship between biological and physical variables was selected according to the coefficient of determination $\left(\mathrm{r}^{2}\right)$.

The relationship between scallop biomass and oceanographic variables was examined within both a generalized linear model (GLM) and a generalized additive model (GAM) framework for comparative purposes (Hastie \& Tibshirani 1990, Guisan \& Thuiller 2005). To this end, biomass estimates and oceanographic variables from the 67 sampling stations were used. Due to overdispersion in abundance data, negative binomial models were used for both GLMs and GAMs; additionally, for the latter, thin plate splines were considered for multidimensional smoothing (Wood 2006). An offset parameter equal to the natural logarithm of the effective swept area sampled was found to be an adequate model for abundance data. All the environmental variables measured were included for model fitting: latitude, longitude, depth, bottom temperature, bottom salinity (hereafter temperature and salinity, respectively), sigma-t $\left(\sigma_{\mathrm{T}}\right)$ and mean chl a. GAMs fit non-parametric functions to estimate the relationships between response and predictor variables without imposing limitations on the form of the underlying relationships. Smoothing parameters, as well as the degrees of freedom (the degree of non-linearity) of the functions from the data, were estimated using the generalized cross-validation (GCV) criterion. An explanatory variable or term in the model was removed (as per Wood 2006) if (1) the estimated degrees of freedom (EDF) for the term were close to $1 ;(2)$ the plotted 
confidence band for the term included zero everywhere; and (3) the GCV score decreased and the deviance explained increased when the term was dropped. Because of correlations among covariates, terms were dropped one at a time, starting with the term for which the zero line was most within the confidence band (Wood 2006). Each model fit was analyzed with respect to the level of deviance explained ( 0 to $100 \%$; the higher the better), the GCV score (the lower the better), and the confidence region for the smooth function (which should not include zeroes throughout the range of the predictor). Akaike's information criterion (AIC), also used to evaluate each model fit and parsimony, accounts for degrees of freedom used and the goodness of fit, such that more parsimonious models have lower AIC (Chambers \& Hastie 1992). The AIC was calculated in R (http://cran.r-project.org/) as -2 log likelihood + 2npar, where npar represents the number of parameters in the fitted model. Residual plots were evaluated for violations of model assumptions. In order to assess whether the non-parametric smooth terms should be simplified to linear terms, we built negative binomial GLMs using the same variables selected by GAMs. Both approaches were then compared by AIC and significances of differences in deviance were checked using approximate $\chi^{2}$ tests (Hastie \& Tibshirani 1990). Finally, spatial GAM biomass predictions were plotted and a polynomial interpolation-extrapolation approach was used to estimate biomass at points not sampled (Wood 2006). Observed $(O)$ and predicted $(P)$ biomasses were plotted and fitted to a linear regression $O=\alpha+\beta P$. Departures from a one-to-one line through the origin indicate model inadequacy, and thus the significance of $\alpha$ and $\beta$ was tested (t-test) under the null hypotheses $\alpha=0$ and $\beta=1$ (Power 1993). All models were estimated by the GAM function in the mgcv and MASS libraries of R.

\section{RESULTS}

\section{Oceanographic patterns}

Latitudinal variations in oceanographic variables are shown in Fig. 2. Temperature and salinity linearly decreased with latitude (Fig. 2a,b), $\sigma_{\mathrm{T}}$ significantly increased with latitude (Fig. 2c), and mean chl a showed 2 marked peaks, the main one at $36^{\circ} 20^{\prime} \mathrm{S}$ $\left(\right.$ mean \pm SE: $3.62 \pm 0.96 \mathrm{mg} \mathrm{m}^{-3}$ ) and a smaller one at the southern border of the surveyed area (36 $50^{\circ} \mathrm{S} ; 2.8$ $\pm 1.48 \mathrm{mg} \mathrm{m}^{-3}$ ). As a result of the above patterns, the northern border of the species distribution at $35^{\circ} 50^{\prime} \mathrm{S}$ had the highest temperature and salinity and the lowest $\sigma_{\mathrm{T}}$ and mean chl a values (Fig. 2). With the exception of mean chl $a$, which was not significantly related to other oceanographic variables, bivariate correlations between temperature, salinity and $\sigma_{\mathrm{T}}$ were all linear and statistically significant $(\mathrm{p}<0.01)$, with the strongest ones found between temperature and: (1) salinity $(\mathrm{r}=0.90)$; and (2) $\sigma_{\mathrm{T}}(\mathrm{r}=0.93)$ (Fig. 2).

Bathymetric variations in temperature, salinity and $\sigma_{\mathrm{T}}$ also followed clear patterns (Fig. 3): (1) temperature was minimum at depths close to $104 \mathrm{~m}$, increasing towards shallower and greater depths; (2) salinity increased with depth; and (3) $\sigma_{\mathrm{T}}$ was maximum at depths close to $120 \mathrm{~m}$, decreasing towards shallower and greater depths. For temperature and salinity, 2 water masses can be clearly distinguished (Fig. 3): from 60 to ca. $120 \mathrm{~m}$ depth, the decreasing pattern in temperature and the low salinity values correspond to the SAW, whereas the highest temperature and salinity values at depths $>120 \mathrm{~m}$ correspond to the STW.

\section{Scallop population patterns}

The biomass of Psychrochlamys patagonica showed 2 clear peaks (Fig. 2): the main one at $36^{\circ} 20^{\prime} \mathrm{S}$ (mean \pm SE: $\left.0.0279 \pm 0.0110 \mathrm{~kg} \mathrm{~m}^{-2}\right)$ and a smaller one at $36^{\circ} 50^{\prime} \mathrm{S}\left(0.0204 \pm 0.0041 \mathrm{~kg} \mathrm{~m}^{-2}\right)$, at the southern border of the surveyed area. At the northern edge of the range of the species distribution $\left(35^{\circ} 50^{\prime} \mathrm{S}\right)$, abundance was 16 times lower $\left(0.0013 \pm 0.0002 \mathrm{~kg} \mathrm{~m}^{-2}\right)$ than at $36^{\circ} 50^{\prime} \mathrm{S}$. As a result of this spatial pattern, scallop abundance was related to mean chl a through an exponential model of the form $B=0.0039 \mathrm{e}^{(0.61 \mathrm{Chlo})}(\mathrm{r}=0.79$; $\mathrm{p}<0.05)$, where $B$ is scallop abundance and Chlo is mean chl a (Fig. 2).

Individual scallop sizes decreased linearly with temperature and salinity, and increased asymptotically with mean chl a (Fig. 4, Table 1). The smallest scallops (mean $H=34 \mathrm{~mm}$ ) were found at the northern distribution edge of the species; these scallops were, on average, $12.7 \mathrm{~mm} \mathrm{(37 \% )} \mathrm{and} 11.5 \mathrm{~mm} \mathrm{(34 \% )} \mathrm{shorter} \mathrm{than}$ those found at $36^{\circ} 30^{\prime} \mathrm{S}$ and $36^{\circ} 50^{\prime} \mathrm{S}$, respectively (Fig. 4, Table 1). Variations in muscle weight for a standard scallop of $60 \mathrm{~mm}$ height $\left(W_{60}\right)$ decreased with temperature, mean chl $a$ and salinity, meaning significantly lower weights at the northern edge of the study area (Fig. 4, Table 1). Indeed, scallops at latitudes $36^{\circ} 30^{\prime} \mathrm{S}, 36^{\circ} 40^{\prime} \mathrm{S}$ and $36^{\circ} 50^{\prime} \mathrm{S}$ were, on average, $11 \%$ heavier than those situated at $36^{\circ} 00^{\prime} \mathrm{S}, 36^{\circ} 10^{\prime} \mathrm{S}$ and $36^{\circ} 20^{\prime} \mathrm{S}$.

\section{GAM and GLM relationships}

GAM results showed that spatial and oceanographic variables significantly $(\mathrm{p}<0.001)$ explained Psychrochlamys patagonica abundance in Uruguayan 


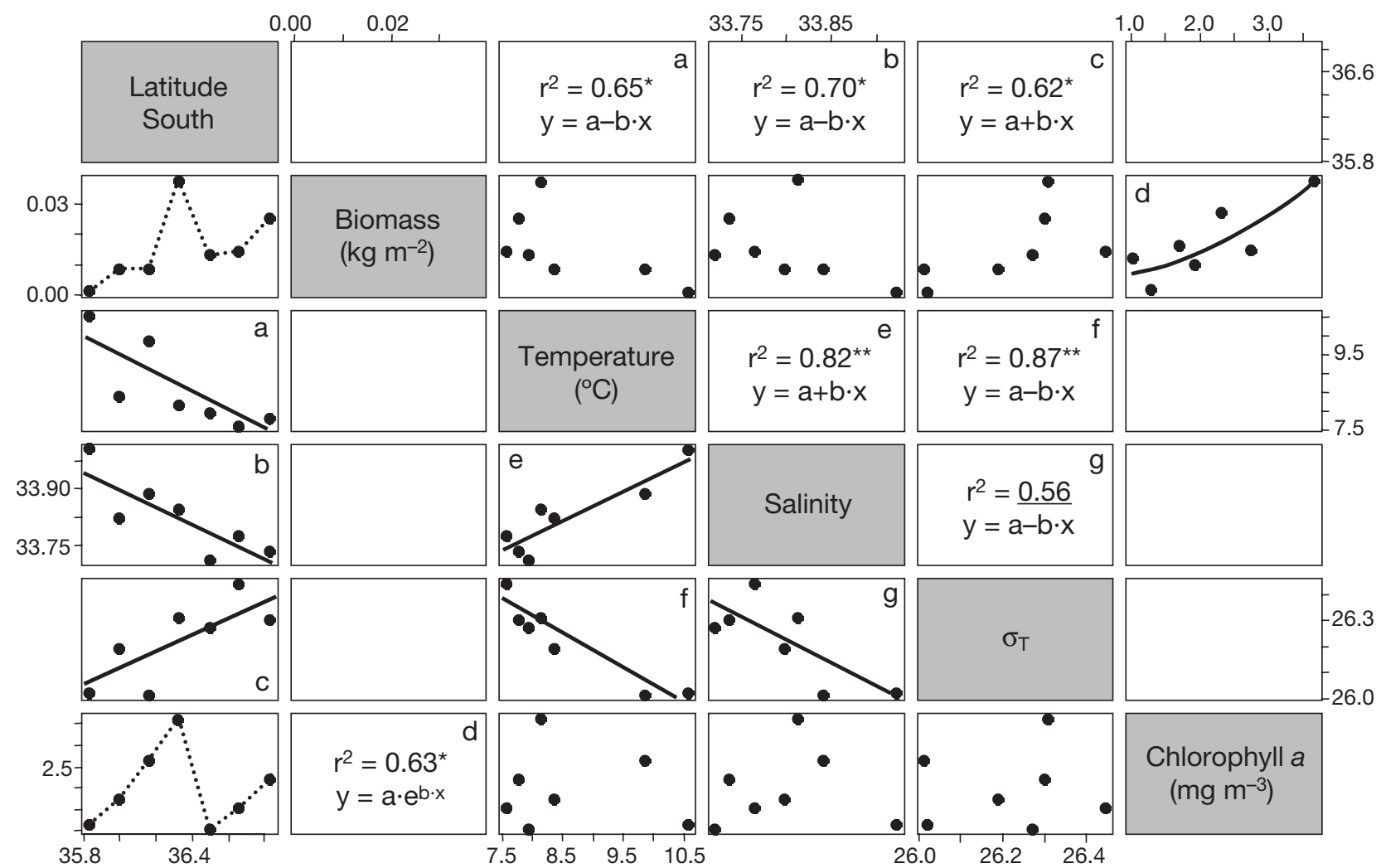

Fig. 2. Psychrochlamys patagonica. Relationships among environmental variables and scallop biomass, averaged by latitude. ${ }^{*} \mathrm{p}<0.05 ;{ }^{* *} \mathrm{p}<0.01$. The underlined value indicates trends that approached significance $(0.10<\mathrm{p}<0.05)$. Latitude is expressed in centesimal units. Note similar latitudinal patterns in mean chl $a$ and scallop biomass. Empty boxes: no relationship found
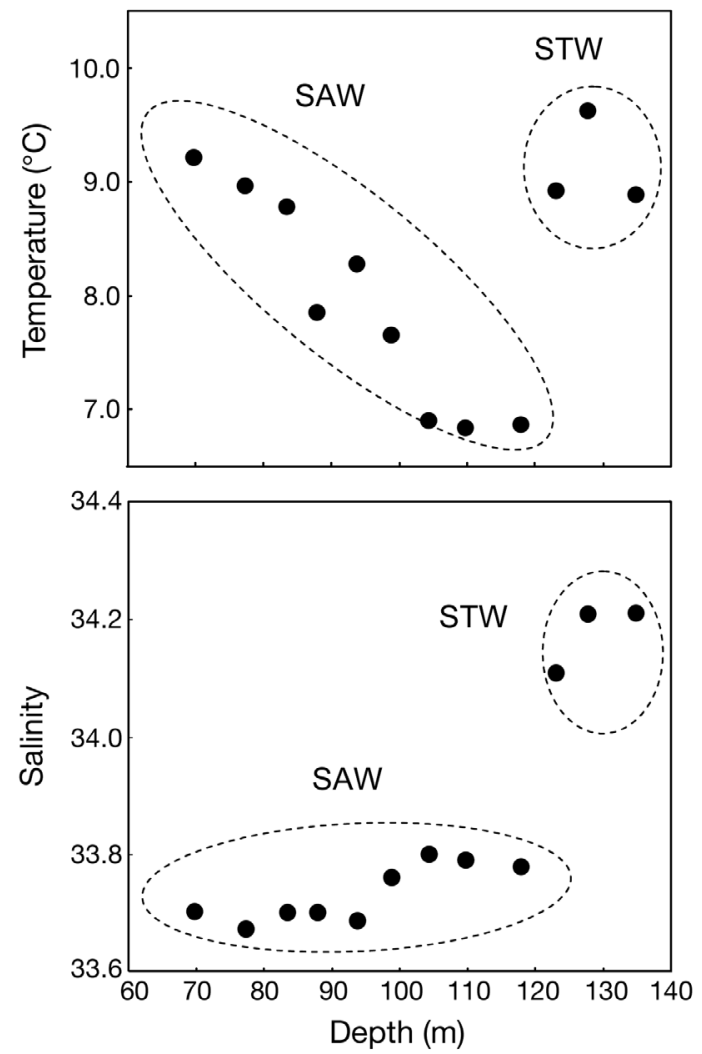

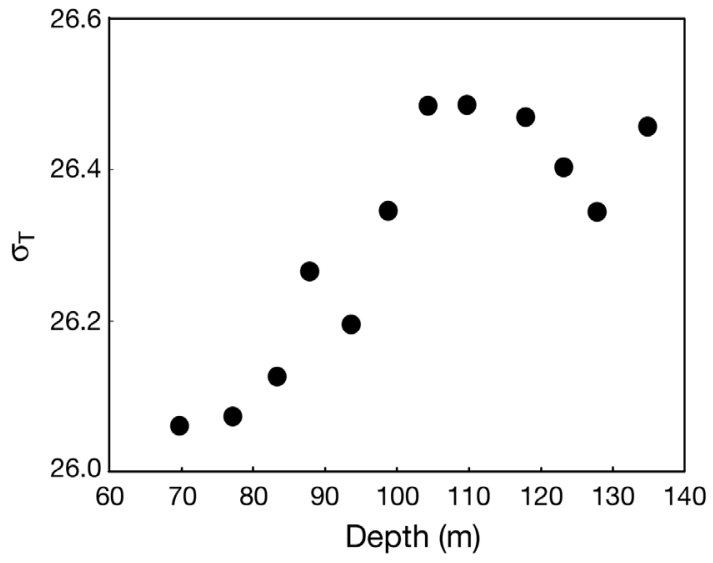

Fig. 3. Bathymetric variations in bottom temperature, salinity and $\sigma_{\mathrm{T}}$. Subantarctic (SAW) and Subtropical (STW) water masses are encircled for temperature and salinity 

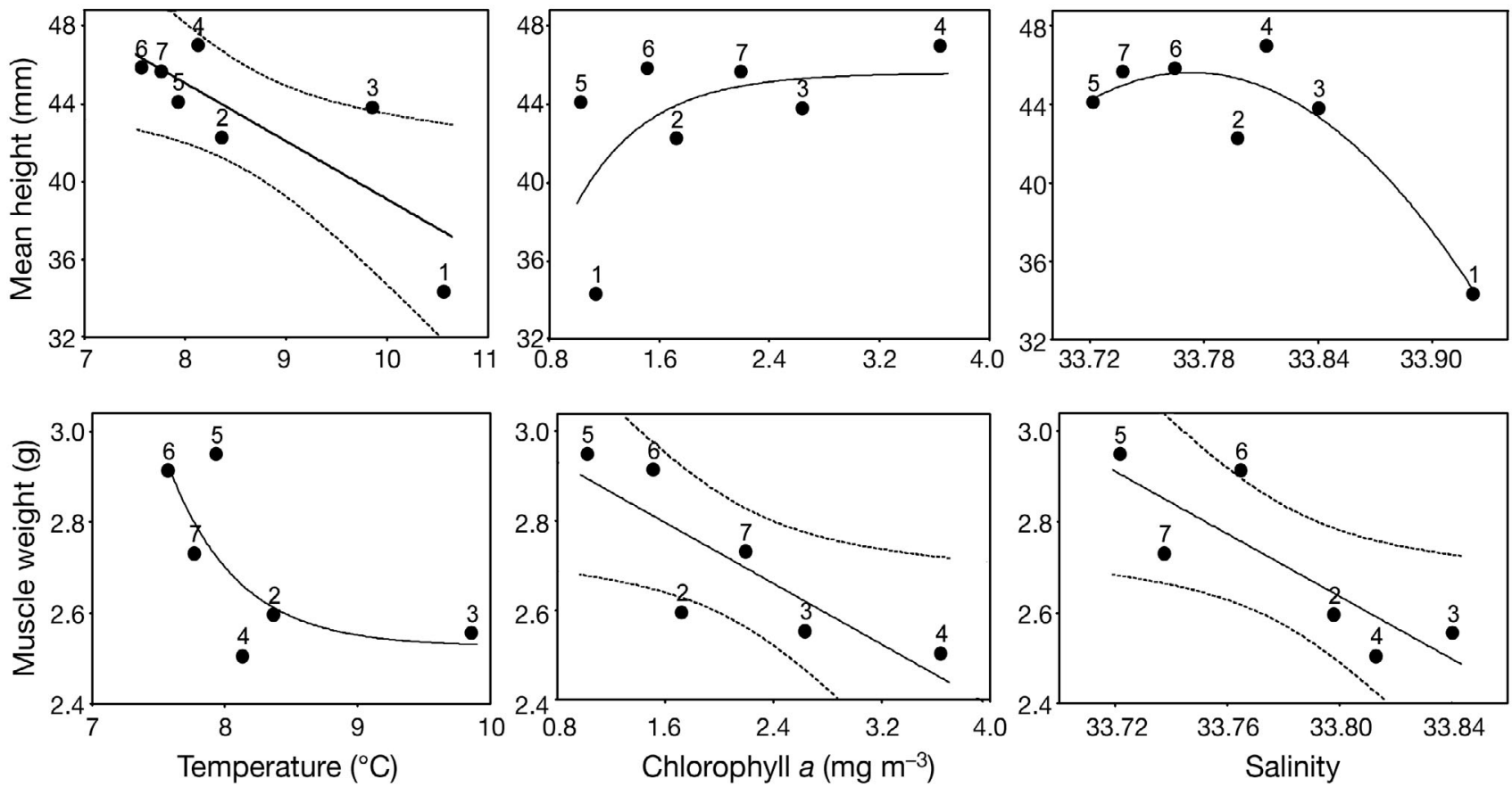

Fig. 4. Psychrochlamys patagonica. Bivariate correlation ( $\pm 95 \% \mathrm{CI}$, dashed lines) between both individual mean height and muscle weight and oceanographic variables (temperature, chl a and salinity). Model with best goodness of fit shown in each case. Numbers by each point refer to sequentially numbered latitudes in north-south direction from $1\left(35^{\circ} 50^{\prime} \mathrm{S}\right.$ : northern edge of the species distribution) to $7\left(36^{\circ} 50^{\prime} \mathrm{S}\right)$

waters, with a good overall fit in terms of their deviance and no abnormalities revealed by the analysis of residuals. The best model included temperature, mean chl $a$ and depth, together with the 'latitudelongitude interaction' (as a proxy for geographic term) (Table 2). This was clearly indicated by the consistent increase in $\mathrm{r}^{2}$ and deviance explained, concurrently with a decrease in the GCV score and AIC between the GAMs fitted with and without the latitude-longitude interaction term (Table 2). Salinity and $\sigma_{\mathrm{T}}$ were

Table 1. Results of bivariate models between some scallop mean height (mm) and muscle weight $(\mathrm{g})$, and oceanographic variables (temperature in ${ }^{\circ} \mathrm{C}$, $\mathrm{chl} a$ in $\mathrm{mg} \mathrm{m}^{-3}$ and salinity). All correlations were significant. $H$ : scallop height; $T$ : bottom temperature; $W_{60}$ : adductor muscle weight of $60 \mathrm{~mm}$ height scallops; Chlo: mean chl a; $S$ : bottom salinity

\begin{tabular}{|lcrr|}
\hline Population feature & Model & $\mathrm{r}$ & $\mathrm{p}$ \\
\hline Temperature & $H=68.91-2.98 T$ & 0.81 & 0.0285 \\
Height & $W_{60}=2.52+94086 \mathrm{e}^{(-1.937 T)}$ & 0.74 & 0.0002 \\
Muscle weight & & & \\
Chl a & $H=45.59\left(1-\mathrm{e}^{(-1.93 \mathrm{Chlo})}\right.$ & 0.54 & $<0.0001$ \\
Height & $W_{60}=3.06-0.17 \mathrm{Chlo}^{(-1.937 T)}$ & -0.83 & 0.0391 \\
Muscle weight & & & \\
Salinity & $H=-5.73 \mathrm{E} 5+33982 S-503 S^{2}$ & -0.76 & 0.0473 \\
Height & $W_{60}=118.90-3.44 S$ & 0.84 & 0.0384 \\
Muscle weight & & & \\
\hline
\end{tabular}

not included in the model $(p>0.05)$. Abundance showed a non-linear relationship with latitudelongitude, increasing southwards and with water depth, peaking between 90 and $110 \mathrm{~m}$, and declining towards shallower and greater depths (Fig. 5). Scallop abundance was negatively related to temperature, and positively with mean chl $a$, with a peak between 5.5 and $6.5 \mathrm{mg} \mathrm{m}^{-3}$. Among the 4 environmental properties considered, the strongest GAM relationships occurred between scallop abundance and temperature, which explained $68 \%$ of the model deviance (Table 2). The GAM clearly achieved lower AIC (Table 2) and an analysis of deviance showed a decrease in the residual deviance of $48.1 \%\left(\mathrm{p}\left[\chi^{2}\right]<0.001\right)$ and $30.5 \%(\mathrm{p}$ $\left.\left[\chi^{2}\right]=0.004\right)$, respectively, when compared to the linear and quadratic GLMs. Thus, the flexibility offered by GAMs significantly improved the quality of the fits. GAM predictions show that scallops mainly occurred above the $100 \mathrm{~m}$ isobath, with major concentrations at the center $\left(36^{\circ} 20^{\prime} \mathrm{S}\right.$ to $\left.36^{\circ} 30^{\prime} \mathrm{S}\right)$ and south $\left(36^{\circ} 50^{\prime} \mathrm{S}\right)$ of Uruguayan waters (Fig. 6). This pattern agrees with the 2 peaks in scallop 
Table 2. Model selection (GLM and GAM) for scallop biomass $\left(\mathrm{kg} \mathrm{m}^{-2}\right)$. Terms that were not significant $(\mathrm{p}>0.05)$ were dropped from the model. Percent of deviance explained, adjusted $\mathrm{r}^{2}$, generalized cross-validation score (GCV) and Akaike information criterion (AIC) are given. EDF: estimated degrees of freedom. Note: As each term is added for GAMs, explained deviance, $\mathrm{r}^{2}$, GCV score and AIC are examined to determine whether the term will be included in the final model (values in bold and italics). Linear and quadratic GLMs were also fitted for comparison purposes, using the variables selected by the best GAM fit. Only most relevant GAM fits were included

\begin{tabular}{|c|c|c|c|c|c|c|}
\hline Model & Terms & EDF & $\begin{array}{c}\text { Deviance } \\
\text { explained (\%) }\end{array}$ & $\mathrm{r}^{2}$ & $\mathrm{GCV}$ & AIC \\
\hline GLM linear & $\begin{array}{l}\text { Biomass } \sim \text { Temperature }+ \text { Chl } a+\text { Depth } \\
+ \text { Longitude } \times \text { Latitude }+ \text { offset (log.Area) }\end{array}$ & 7.00 & 42.7 & 0.067 & 1.11 & 621 \\
\hline GLM quadratic & $\begin{array}{l}\text { Biomass } \sim \text { Temperature }+(\text { Temperature })^{2}+\mathrm{Chl} a+(\mathrm{Chl} a)^{2} \\
+ \text { Depth }+(\text { Depth })^{2}+\text { Longitude } \times \text { Latitude }+ \text { offset }(\text { log.Area })\end{array}$ & 9.00 & 59.0 & 0.299 & 1.16 & 598 \\
\hline GAM & Biomass $\sim \mathrm{s}($ Temperature $)+$ offset (log.Area) & 3.04 & 65.3 & 0.133 & 1.05 & 615 \\
\hline GAM & $\begin{array}{l}\text { Biomass s(Temperature })+\mathrm{s}(\mathrm{Chl} a)+\mathrm{s}(\text { Depth }) \\
+ \text { offset (log.Area) }\end{array}$ & 13.93 & 68.7 & 0.245 & 1.23 & 595 \\
\hline GAM & $\begin{array}{l}\text { Biomass } \sim \mathrm{s} \text { (Temperature) }+ \text { s(Longitude, Latitude) } \\
+ \text { offset (log.Area) }\end{array}$ & 21.52 & 73.1 & 0.209 & 1.47 & 586 \\
\hline GAM & $\begin{array}{l}\text { Biomass } \sim \mathrm{s}(\text { Temperature })+\mathrm{s}(\mathrm{Chl} a)+\mathrm{s}(\text { Longitude, Latitude }) \\
+\mathrm{s}(\text { Depth })+\text { offset (log.Area) }\end{array}$ & 21.99 & 78.7 & 0.303 & 1.19 & 576 \\
\hline
\end{tabular}
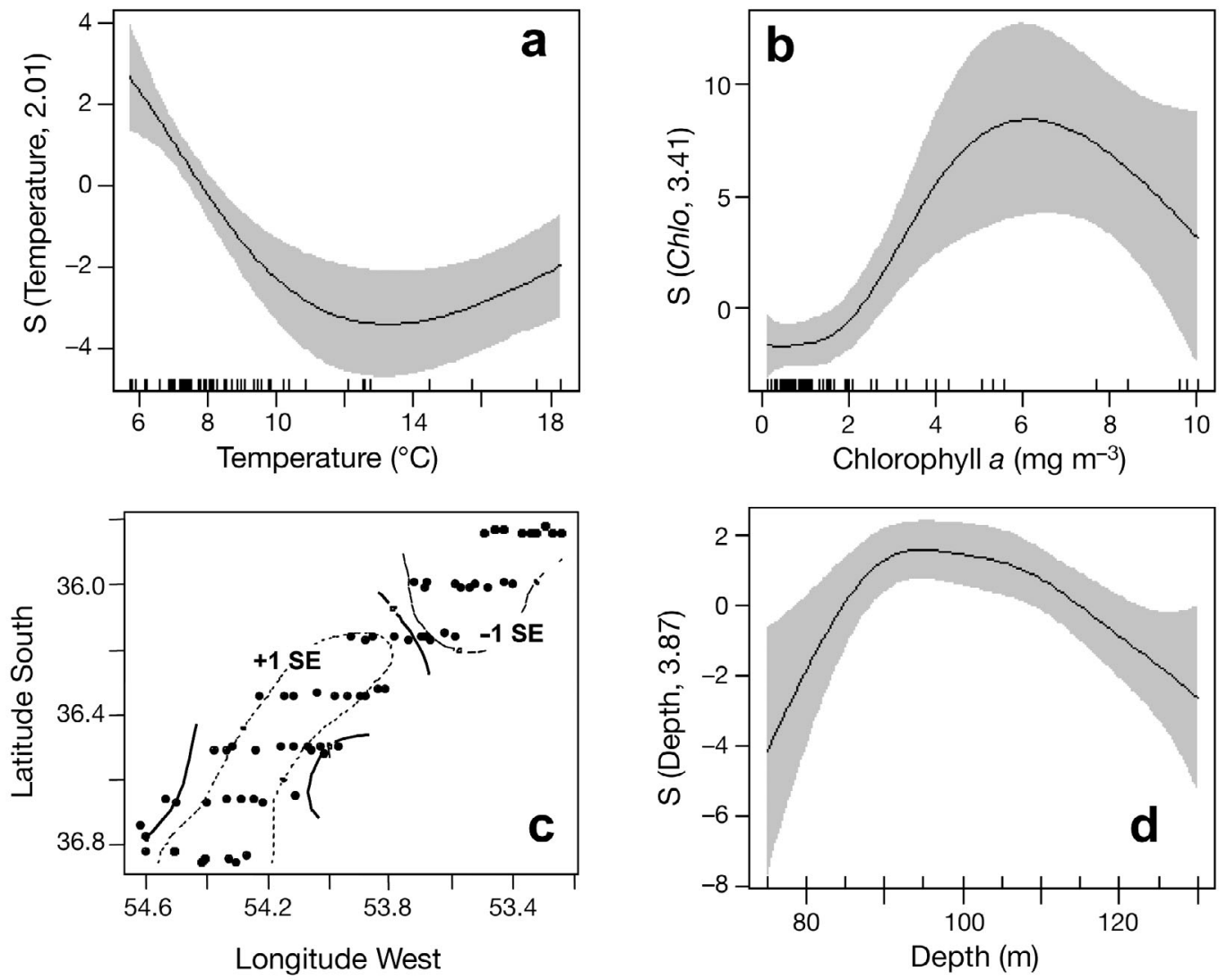

Fig. 5. Psychrochlamys patagonica. Results of GAM showing relationship (solid line) between abundance and each meaningful environmental predictor: (a) temperature, (b) mean chl a (Chlo), (c) latitude-longitude and (d) depth. Shaded areas indicate 2 SE above and below estimate of the smooth curve. 'Rug plots' on the $x$-axis indicate range of variables over which measurements were taken. S on the $y$-axis represents the smooth function (spline) for scallop abundance and numbers next to variable name are the estimated degrees of freedom (EDF). For latitude/longitude, bivariate smooth shown as a contour plot with surfaces at +1 and $-1 \mathrm{SE}$ over the survey area and sampled locations marked by dots 


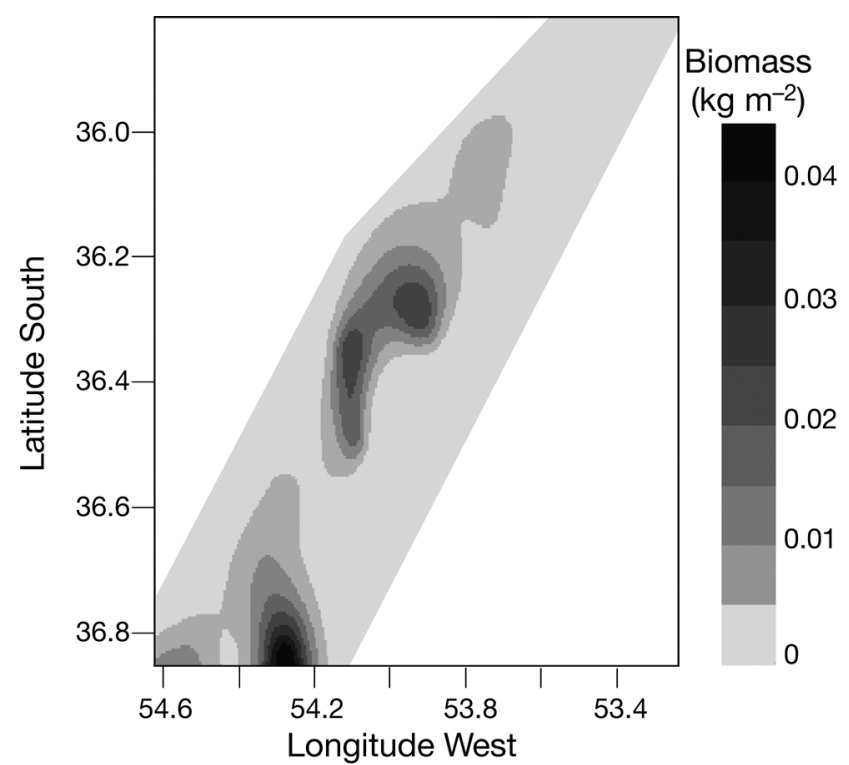

Fig. 6. Psychrochlamys patagonica. GAM predictions of abundance through image plots. Latitude and longitude are expressed in centesimal units

biomass shown in Fig. 2. The correlation between observed and predicted abundance was significant ( $\left.\mathrm{p}<0.001 ; \mathrm{r}^{2}=0.98\right)$ and the null hypotheses $\alpha=0$ and $\beta=1$ were not rejected $(O=3.12+0.96 P ; \mathrm{p}>0.50)$.

\section{DISCUSSION}

Some of the mechanisms limiting species ranges include environmental gradients (temperature: Heilmayer 2003), dispersal barriers (ocean flows: Gaylord \& Gaines 2000), and biological interactions (competition: Case et al. 2005). In the present study, the strong relationships between scallop abundance and environmental variables, mainly temperature, imply the existence of an environmental margin (sensu Bridle \& Vines 2007) at the northern limit of Psychrochlamys patagonica distribution. The species showed strong spatial patterns in abundance, individual size and muscle weight in Uruguayan waters. All these population descriptors significantly decreased towards the northern edge of the population distribution, where sea temperature and salinity were highest, and chl a was lowest. The species distribution was also strongly restricted to a depth range between 75 and $135 \mathrm{~m}$, associated with the thermohaline properties of the SAW.

A distinctive pattern of oceanographic conditions was noticeable in this study, related with the confluence of the Brazil and Malvinas/Falkland currents (see also Ortega \& Martinez 2007). Both latitudinal and bathymetric patterns shown in this study revealed the presence of 2 distinct water masses, the SAW and the STW, associated with these currents. Considering these water masses with contrasting thermohaline characteristics, the species' northern border of distribution could be primarily explained by the strong gradient occurring at this oceanographic discontinuity. Several macroinvertebrates, such as the gastropods Odontocymbiola magellanica and Adelomelon ancilla (common predators of Psychrochlamys patagonica: Botto et al. 2006), also have the same northern border of distribution in the SAO (Olivier \& Scarabino 1972). Thermohaline gradients have been associated with biogeographic boundaries worldwide, constraining species' geographical ranges (Wilson et al. 1996, Gaylord \& Gaines 2000).

The GAM built here was useful to model scallop/ habitat relationships and to predict spatial variations in abundance at the northern limit of the scallop's distribution range. Better fits obtained with GAM when compared to those obtained with linear and quadratic GLMs are based on the rationale that the response of scallop abundance along environmental predictors is neither linear nor monotonic. Hence, this more flexible framework resulted in more realistic and informative models. Many of the relationships between environmental features and scallop distribution were nonlinear (Table 2). Although depth, temperature and chl a significantly influenced scallop distribution and abundance, the most parsimonious GAM fitted included a latitude-longitude interaction (as a proxy for location). This interaction reflects localized biological processes (e.g. attraction by conspecifics) or the result of a process in which much of the pattern is driven by spatial correlation (Swartzman et al. 1992, Wood \& Augustin 2002). Including location in our GAM also improved the spatial predictive ability of the model, highlighting the 2 main high scallop biomass patches. The effects derived by the latitude-longitude interaction, which cannot be quantified separately, are of the utmost importance in shaping macroscale patterns in the scallop population.

Spatial distribution patterns of Psychrochlamys patagonica in the northern limit of its range could be related to the presence of the shelf break front created by the SAW-STW confluence (Ortega \& Martínez 2007). This front is characterized by a steep gradient in oceanographic variables and high chl a concentrations (Martínez \& Ortega 2007). These concentrations are important for $P$. patagonica as a suspension-feeder, particularly when it is feeding on phytoplankton (Schejter et al. 2002). However, the decrease in scallop abundance at chl a values $>6.0 \mathrm{mg} \mathrm{m}^{-3}$ (Fig. 5b) could be explained by the high temperatures occurring in the SAW-STW confluence; these higher temperatures may decrease the effect of food availability on scallop abundance. 
GAM relationships predicted a sharp decrease in abundance at temperatures above $9^{\circ} \mathrm{C}$, reaffirming this value as the upper limit of temperature tolerance of this species (Heilmayer et al. 2001). The results agree with recent findings showing that temperature is one of the major determinants of habitat suitability for scallop resources (Heilmayer 2003 and references therein) and that species distribution patterns commonly reflect gradients or discontinuities in temperature adaptation (Guisan et al. 2006). A strong empirical relationship between growth efficiency and temperature found in scallops reinforces the idea of a temperature-optimum growth efficiency in these organisms (Heilmayer 2003). Gutiérrez \& Defeo (2005) also found that growth rates of Psychrochlamys patagonica drastically decreased at the northern edge of its distributional range. Moreover, the decrease in mean individual height and muscle weight with increasing temperature shown in this study could be ascribed to phenotypic plasticity in response to extreme oceanographic conditions, strengthening the hypothesis of environmental limitation at the northern edge of the geographical range of the species. High adult scallop mortalities found at the northern border of the species distribution (Gutiérrez \& Defeo 2005) also suggest that thermohaline properties affect the scallop's population dynamics. This is in agreement with the hypothesis that higher mortality caused by adverse environmental conditions in fringe populations is the main mechanism setting the range limits (Zacherl et al. 2003).

In order to understand species range limits, 3 broad questions have to be addressed (Gaston 2003): (1) What biotic and abiotic factors prevent further spread? (2) How do these aspects affect a species' population dynamics? (3) What are the genetics behind species' response to factors determining these range limits? Previous work by Defeo \& Gutiérrez (2003) and Gutiérrez \& Defeo (2005) and the present study answered the first 2 questions. The northernmost limit of Psychrochlamys patagonica could be ascribed mainly to abrupt changes in temperature associated with the Brazil-Malvinas/Falklands Confluence, where water reaches temperatures beyond the species' tolerance limit. These prevailing stressful environmental conditions at the northern edge of distribution cause poor and irregular recruitment, low growth rates and high natural mortality (Gutiérrez \& Defeo 2005). Thus, the environmental constraints defined in this study play an important role in determining the population dynamics of this marginal population and therefore its northern distributional range. Whereas temperature seems to be the main variable determining scallop occurrence, mean chl a has a strong effect on abundance, with peaks in chl a exactly matching high-biomass scallop patches.
Acknowledgements. This paper is part of the MSc thesis of N.L.G. We express our gratitude to our colleagues and friends who helped us during the survey and in the laboratory. A. E. Punt (University of Washington) and 3 anonymous referees provided useful suggestions on improving the paper. Financial support from DINARA and PEDECIBA Uruguay is gratefully acknowledged.

\section{LITERATURE CITED}

Acha EM, Mianzán HW, Guerrero RA, Favero M, Bava J (2004) Marine fronts at the continental shelves of austral South America. Physical and ecological processes. J Mar Syst 44:83-105

Arnold WS, Marelli DC, Bray CP, Harrison MM (1998) Recruitment of bay scallops Argopecten irradians in Floridian Gulf of Mexico: scales of coherence. Mar Ecol Prog Ser 170:143-157

Bakun A, Parrish RH (1991) Comparative studies of coastal pelagic fish reproductive habitats: the anchovy (Engraulis anchoita) of the southwestern Atlantic. ICES J Mar Sci 48: 343-361

Bogazzi E, Baldoni A, Rivas A, Martos P and 5 others (2005) Spatial correspondence between areas of concentration of Patagonian scallop Zygochlamys patagonica and frontal systems in the Southwestern Atlantic. Fish Oceanogr 14: 359-376

Botto F, Bremec C, Marecos A, Schejter L, Lasta M, Iribarne O (2006) Identifying predators of the SW Atlantic Patagonian scallop Zygochlamys patagonica using stable isotope analysis. Fish Res 81:45-50

Brandini FP, Boltovskoy D, Piola A, Kocmur S, Röttgers R, Abreu PC, Lopes RM (2000) Multiannual trends in fronts and distribution of nutrients and chlorophyll in the southwestern Atlantic (30-62 $\left.{ }^{\circ} \mathrm{S}\right)$. Deep-Sea Res I 47:1015-1033

Bridle JR, Vines TH (2007) Limits to evolution at range margins: when and why does adaptation fail? Trends Ecol Evol 22:140-147

Caddy JF (1979) Some considerations underlying definitions of catchability and fishing effort in shellfish fisheries, and their relevance for stock assessment purposes. Manuscr Rep Dep Fish Oceans (Can) 1489:1-18

Caddy JF (1989) A perspective on the population dynamics and assessment of scallop fisheries, with special reference to sea scallop, Placopecten magellanicus (Gmelin). In: Caddy JF (ed) Marine invertebrate fisheries: their assessment and management. Wiley-Interscience Publication, New York, p 559-589

Carreto JI, Lutz VA, Carignan MO, Cucchi Colleoni AD, De Marco SG (1995) Hydrography and chlorophyll $a$ in a transect from the coast to the shelf-break in the Argentinian Sea. Cont Shelf Res 15:315-336

Case TJ, Holt RD, McPeek MA, Keitt TH (2005) The community context of species' borders: ecological and evolutionary perspectives. Oikos 108:28-46

Chambers J, Hastie T (1992) Statistical models in S. Wadsworth \& Brooks/Cole Advanced Books and Software, Pacific Grove, CA

Christophersen G, Strand $\varnothing$ (2003) Effect of reduced salinity on the great scallop (Pecten maximus) spat at two rearing temperatures. Aquaculture 215:79-92

Cusson M, Bourget E (2005) Global patterns of macroinvertebrate production in marine benthic habitats. Mar Ecol Prog Ser 297:1-14

Defeo O, Brazeiro A (1994) Distribución, estructura poblacional y relaciones biométricas de la vieira Zygochlamys 
patagonica en aguas uruguayas. Com Soc Malac Urug VII:362-367

Defeo O, Gutiérrez N (2003) Geographical patterns in growth estimates of the scallop Zygochlamys patagonica, with emphasis on Uruguayan waters. J Shellfish Res 22: 643-646

Emilsson I (1961) The shelf and coastal waters off southern Brazil. Bolm Inst Oceanogr S Paulo 11:101-112

Freeman SM, Rogers SI (2003) A new analytical approach to the characterization of macro-epibenthic habitats: linking species to the environment. Estuar Coast Shelf Sci 56: 749-764

Gaston KJ (2003) The structure and dynamics of geographic ranges. Oxford University Press, Oxford

Gaylord B, Gaines SD (2000) Temperature or transport? Range limits in marine species mediated solely by flow. Am Nat 155:769-789

Guisan A, Thuiller W (2005) Predicting species distribution: offering more than simple habitat models. Ecol Lett 8: 993-1009

Guisan A, Lehmann A, Ferrier S, Austin M, Overton J, Aspinall R, Hastie T (2006) Making better biogeographical predictions of species' distributions. J Appl Ecol 43:386-392

Gutiérrez N, Defeo O (2003) Development of a new scallop Zygochlamys patagonica fishery in Uruguay: latitudinal and bathymetric patterns in biomass and population structure. Fish Res 62:21-36

Gutiérrez NL, Defeo O (2005) Spatial patterns in population dynamics of the scallop Psychrochlamys patagonica at the northern edge of its range. J Shellfish Res 24:877-882

Hastie T, Tibshirani RJ (1990) Generalized additive models. Chapman \& Hall, London

Heilmayer O (2003) Environment, adaptation and evolution: scallops ecology across the latitudinal gradient. $\mathrm{PhD}$ thesis, Alfred Wegener Institute for Polar and Marine Research, Bremerhaven

Heilmayer O, Bremec C, Brey T, Lasta M, Valero J (2001) Why are there no Patagonian scallops (Zygochlamys patagonica) north of the Rio Plata estuary? Proc 13th International Pectinid Workshop, Coquimbo

Jeffrey SW, Humphrey GF (1975) New spectrophotometric equations for determining chlorophylls $a, b, c_{1}$ and $c_{2}$ in higher plants, algae and natural phytoplankton. Biochem Physiol Pflanz 167:191-194

Jensen O, Seppelt R, Miller TJ, Bauer LJ (2005) Winter distribution of blue crab Callinectes sapidus in Chesapeake Bay: application and cross-validation of a two-stage generalized additive model. Mar Ecol Prog Ser 299:239-255

Jonkers HA (2003) Late Cenozoic-Recent Pectinidae (Mollusca: Bivalvia) of the Southern Ocean and neighbouring regions. Monogr Mar Mollusca 5:1-125

Kater BJ, Geurts van Kessel AJM, Baars JMD (2006) Distribution of cockles Cerastoderma edule in the Eastern Scheldt: habitat mapping with abiotic variables. Mar Ecol Prog Ser 318:221-227

Katsanevakis S (2005) Abundance and spatial distribution of the Mediterranean scallop, Pecten jacobaeus, in a marine lake. Fish Res 76:417-429

Lasta ML, Iribarne OO (1997) Southern Atlantic scallop

Editorial responsibility: Howard Browman (Associate Editorin-Chief), Storebø, Norway
(Zygochlamys patagonica) fishery: assessment of gear efficiency through a depletion experiment. J Shellfish Res 16:59-62

Martínez A, Ortega L (2007) Seasonal trends in phytoplankton biomass over the Uruguayan shelf. Cont Shelf Res 27:1747-1758

Olivier S, Scarabino V (1972) Distribución ecológica de algunos moluscos recogidos por la expedición del ' Walther Herwig' (R.F.A.) al Atlántico Sudoccidental (1966). Rev Brasil Biol 32:235-247

Ortega L, Martínez A (2007) Multiannual and seasonal variability of water masses and fronts over the Uruguayan shelf. J Coast Res 23:618-629

Parsons TR, Maita Y, Lalli CM (1984) A manual of chemical and biological methods for seawater analysis. Pergamon Press, New York

Portner HO (2002) Climate variations and the physiological basis of temperature dependent biogeography: systemic to molecular hierarchy of thermal tolerance in animals. Comp Biochem Physiol A 132:739-761

Power M (1993) The predictive validation of ecological and environmental models. Ecol Model 68:33-50

Sagarin RD, Gaines SD, Gaylord B (2006) Moving beyond assumptions to understand species abundance distribution across the ranges of species. Trends Ecol Evol 21: 524-530

Schejter L, Bremec CS, Akselman R, Hernández D, Spivak E (2002) Annual feeding cycle of the Patagonian scallop Zygochlamys patagonica (King and Broderip, 1832) in Reclutas bed $\left(39^{\circ} \mathrm{S}-55^{\circ} \mathrm{W}\right)$, Argentine sea. J Shellfish Res 21:549-555

Sinclair M, Mohn RK, Probert G, Roddick DL (1985) Considerations for the effective management of Atlantic scallops. Can Tech Rep Fish Aquat Sci 1382:97

Stokesbury KDE (2002) Estimation of sea scallop abundance in closed areas of Georges Bank, USA. Trans Am Fish Soc 131:1081-1092

Sverdrup HU, Johnson M, Fleming R (1942) The Oceans. Their physics, chemistry and general biology. Prentice Hall, New York

Swartzman G, Huang C, Kaluzny S (1992) Spatial analysis of Bering Sea groundfish survey data using generalized additive models. Can Fish Aquat Sci 49:1366-1378

Thomsen H (1962) Masas de agua características del Océano Atlántico (parte Sudoeste). Servicio de Hidrografía Naval, Secretaría Marina, Publ H632, Buenos Aires

Wilson GW, Nisbet RM, Ross HA, Robles C, Desharnais RA (1996) Abrupt population changes along smooth environmental gradients. Bull Math Biol 58:907-922

Wood SN (2006) Generalized additive models: an introduction with R. CRC/Chapman \& Hall, London

Wood SN, Augustin NH (2002) GAMs with integrated model selection using penalized regression splines and applications to environmental modelling. Ecol Model 157: 157-177

Zacherl D, Gaines SD, Lonhart SI (2003) The limits of biogeographical distributions: insights from the northward range extension of the marine snail, Kelletia kelletii (Forbes, 1852). J Biogeogr 30:913-924

Submitted: March 13, 2007 Accepted: July 30, 2007 Proofs received from author(s): December 14, 2007 